\title{
Movement disorders in astrocytomas of the basal ganglia and the thalamus
}

Joachim K Krauss, Fritz Nobbe, Ajay K Wakhloo, Mohsen Mohadjer, Werner Vach, Fritz Mundinger

\begin{abstract}
In a series of 225 patients with astrocytomas (grades I-IV) of the basal ganglia and the thalamus, 20 had a movement disorder. In all patients the histological diagnosis was verified by stereotactic biopsy. Tremor was observed in twelve patients, dystonia in eight, chorea in three, and chorea/ballismus and myoclonus in one. The tumour involved the thalamus in 16 patients. Corticospinal tract dysfunction was evident in $70 \%$ of the patients with movement disorders and in $73 \%$ of those without. Demographic, clinical, histological and neuroradiological data of the patients with a movement disorder were compared with the data of patients without. CT data yielded no differences with respect to the involvement of anatomical structures. Movement disorders were significantly associated with low-grade astrocytomas.
\end{abstract}

(F Neurol Neurosurg Psychiatry 1992;55:1162-1167)

Tumours of the thalamus and the basal ganglia are relatively rare. They are estimated to make up $1-2 \cdot 5 \%$ of intracranial tumours. ${ }^{1-4}$ Most of these neoplasms are benign or malignant astrocytomas. ${ }^{5-7}$ Since craniotomy and partial resection was associated with high mortality and morbidity, stereotactic diagnostic and therapeutic techniques have been favoured in recent years. $^{78}$

As movement disorders (MDs) are often related to dysfunction or structural lesions of the basal ganglia, a high incidence in intrinsic tumours might be expected, but they seem to be infrequent. While in some series they are not even mentioned, ${ }^{9}$ they range from $1-7 \%$ in recent $^{57}$ and from $4-33 \%$ in earlier series. ${ }^{34}$

Since $1965,{ }^{10}$ no large series has focused on the subject. To characterise better this relatively uncommon cause of MDs, we reviewed the literature and retrospectively analysed a series of 225 patients with histologically verified astrocytomas of the basal ganglia and the thalamus. Among those we identified 20 with MDs (classified according to criteria published elsewhere) ${ }^{11-16}$ at the time of biopsy.

\section{Methods}

This study is based on a retrospective evaluation of 225 patients with low- or high-grade astrocytomas of the basal ganglia and the thalamus histologically confirmed by stereo- tactic biopsy. Fifteen patients were operated on before 1975 and 210 between 1975-86. The patients were referred from other neurosurgical or neurological clinics to the department of stereotaxy. CT scans, (available in our institution since 1975) and also MRI were later obtained before biopsy. In patients operated upon before 1975, CT was performed as soon as it became available. The patients were followed up at various times, with latest follow ups in 1989, 90 or 91. Patients' clinical reports, the register of a tumour data bank, and film recordings were reviewed to identify 20 patients with MDs.

Stereotactic biopsy and interstitial radiotherapy were performed using the RiechertMundinger system as described elsewhere. ${ }^{17}{ }^{19}$ The histological diagnosis was made using intraoperative smear preparations by methylene blue staining and was confirmed with paraffin sections. The tumours were graded according to the classification of the World Health Organisation (WHO).

Demographic, clinical and histopathological data of patients with an MD were compared with those of patients without. For statistical analysis Fisher's exact test, the Wilcoxon, and the Chi-square test were applied.

\section{Results}

Twenty (9\%) patients with astrocytomas of the basal ganglia and the thalamus displayed an $M D$ at the time of biopsy. The MD was the initial symptom of the tumour in three patients. The mean latency between onset of any symptoms and biopsy was 3 years. Various other clinical symptoms were found (table 1). Signs of raised intracranial pressure at biopsy were evident in patients $2,5,6,8$, and 15 . Obstructive hydrocephalus at biopsy was found in patients 5, 6, and 8. Five patients had received ventriculoatrial or ventriculoperitoneal shunts before stereotactic biopsy. Two had no MD before the shunt operation, in two others shunting did not alter the MD, and in patient 14 hemiparesis improved while tremor did not.

CT or additional MRI findings were obtained in 18 of the 20 patients (two had died before 1975). The tumour involved the thalamus in 16. Downward extension to the subthalamus or the upper midbrain varied. This could not always be determined exactly due to the compressive effect of the tumour on adjacent structures or due to peritumoural oedema, or because some patients had had only axial CT scans. In 15 patients the tumour 
Table 1 Clinical features, histological grading and neuroradiological findings of 20 patients with movement disorders in basal ganglia and thalamic astrocytomas

\begin{tabular}{|c|c|c|c|c|c|c|c|c|}
\hline Case & $\begin{array}{l}\text { Sex/Age at } \\
\text { Biopsy/Age } \\
\text { at Onset }\end{array}$ & $\begin{array}{l}\text { Preop. } \\
\text { KPS }\end{array}$ & Movement Disorder & $\begin{array}{l}\text { Other Clinical Symptoms } \\
\text { at Biopsy }\end{array}$ & Hemiparesis & $\begin{array}{l}\text { Grade of } \\
\text { Astrocytoma }\end{array}$ & Brain Imaging Study Results & $\begin{array}{l}\text { Tumour } \\
\text { Volume } \\
\mathrm{cm}^{3}\end{array}$ \\
\hline 1 & $\mathrm{M} / 25 / 13$ & 60 & $\begin{array}{l}\text { Tremor, } 3-4 \mathrm{~Hz} \\
1 \text { arm: rest, post, int }\end{array}$ & $\mathrm{R}$ hypacusis, nystagmus & - & I & $\begin{array}{l}\text { R thalamus, cyst extending to midbrain } \\
\text { (circumscribed) }\end{array}$ & $\sim 25$ \\
\hline 2 & $\mathbf{M} / 3 / 3$ & 80 & $\begin{array}{l}\text { Tremor, } 3-5 \mathrm{~Hz} \\
1 \text { arm > leg: post, int } \\
\text { Athetosis, } 1 \text { hand: rest } \\
\text { Head tilt }\end{array}$ & Papilloedema & - & I & $\begin{array}{l}\mathrm{R} \text { thalamus, internal capsule, pallidum } \\
\text { (circumscribed) }\end{array}$ & $\sim 22$ \\
\hline 3 & M/50/44 & 60 & $\begin{array}{l}\text { Tremor, } 3-4 \mathrm{~Hz} \\
1 \text { arm > leg: rest, post, int }\end{array}$ & $\begin{array}{l}R \text { optic atrophy, } r \text { 3rd } \\
\text { nerve palsy, dysarthria, } \\
\text { gait ataxia }\end{array}$ & $\mathbf{L}$ & I & $\begin{array}{l}\text { R postero-basal thalamus, nucleus ruber } \\
\text { (circumscribed) }\end{array}$ & $\sim 1.5$ \\
\hline 4 & $F / 49 / 43$ & 60 & $\begin{array}{l}\text { Chorea } \\
\text { face, bilateral } 1>\mathrm{r} \\
1 \text { arm }>\text { leg }\end{array}$ & $\begin{array}{l}\text { Impaired memory, } \\
\text { seizures }\end{array}$ & L & $\begin{array}{l}\text { II } \\
\text { II-III (8m) }\end{array}$ & $\begin{array}{l}\mathbf{R} \text { frontomedial, basal, septum } \\
\text { pellucidum, corpus callosum, caudate } \\
\text { (diffuse) }\end{array}$ & $>50$ \\
\hline 5 & $\mathrm{~F} / 70 / 70$ & 40 & $\begin{array}{l}\text { Parkinsonism hypokinesia, } \\
\text { bilateral rigidity + tremor: } \\
\text { rest, post, int }\end{array}$ & $\begin{array}{l}\text { Impaired memory, } \\
\text { obstructive } \\
\text { hydrocephalus, } \\
\text { Parinaud's syndrome, } \\
\text { lethargy }\end{array}$ & - & IV & $\begin{array}{l}\mathrm{R}+\mathrm{L} \text { posteromedial thalamus, 3rd } \\
\text { ventricle, corpus pineale, splenium } \\
\text { corporis callosi (circumscribed)-upper } \\
\text { brainstem compression }\end{array}$ & $\sim 20$ \\
\hline 6 & $\mathrm{M} / 37 / 31$ & 60 & $\begin{array}{l}\text { Tremor, } 4-5 \mathrm{~Hz} \\
1 \text { arm: rest, post, int }\end{array}$ & $\begin{array}{l}\text { Impaired memory, } \\
\text { seizures, aphasia }\end{array}$ & - & II & $\begin{array}{l}\mathbf{R} \text { thalamus, internal capsule, pallidum, } \\
\text { putamen, corpus callosum, septum } \\
\text { pellucidum, } \mathbf{r} \text { frontal + temporal, } \\
\text { I frontal (diffuse) }\end{array}$ & $>100$ \\
\hline 7 & $F / 11 / 10$ & 60 & $\begin{array}{l}\text { Dystonia } \\
1 \text { arm: rest, on action }\end{array}$ & $\begin{array}{l}\text { Lethargy, } \\
\text { Neurofibromatosis } \\
\text { type I }\end{array}$ & L & I & $\begin{array}{l}\mathbf{R} \text { pallidum, subthalamus, internal } \\
\text { capsule (circumscribed) }+ \\
\text { quadrigeminal plate }+ \text { bilateral pons }+ \\
\text { cerebellum (diffuse) }\end{array}$ & $\sim 12$ \\
\hline 8 & $M / 12 / 9$ & 70 & $\begin{array}{l}\text { Dystonia } \\
1 \text { hand: on action } \\
\text { Tremor, } 4-5 \mathrm{~Hz} \\
1 \text { arm: post, int }\end{array}$ & $\begin{array}{l}\text { Impaired memory, } \\
\text { obstructive } \\
\text { hydrocephalus, } \\
1 \text { hemihypaesthesia, 1 6th } \\
\text { nerve palsy, Parinaud's } \\
\text { syndrome }\end{array}$ & L & I & $\mathbf{R}$ thalamus (circumscribed) & $\sim 15$ \\
\hline 9 & $M / 42 / 41$ & 70 & $\begin{array}{l}\text { Tremor, } 4 \mathrm{~Hz} \\
\mathrm{r} \text { arm: rest, post, int }\end{array}$ & Seizures, headaches & - & II & $\begin{array}{l}\text { L basal ganglia }+ \text { hemisphere, corpus } \\
\text { callosum (diffuse, multifocal) }\end{array}$ & $>100$ \\
\hline 10 & $\mathrm{M} / 25 / 25$ & 60 & $\begin{array}{l}\text { Dystonia } \\
\mathrm{r} \text { arm: rest, on action }\end{array}$ & $\begin{array}{l}\text { Impaired memory, } \\
\text { aphasia, behavioural } \\
\text { disorder, seizures, } \\
\text { r hemihypaesthesia }\end{array}$ & $\mathbf{R}$ & I & $\begin{array}{l}\text { L thalamus, subthalamus, caudate, } \\
\text { putamen, pallidum, internal capsule, } \\
\text { corona radiata (circumscribed) }\end{array}$ & $\sim 40$ \\
\hline 11 & M/15/13 & 70 & $\begin{array}{l}\text { Tremor, } 4-5 \mathrm{~Hz} \\
\mathrm{r} \text { arm: rest, post, int }\end{array}$ & Impaired memory & $\mathbf{R}$ & I & $\begin{array}{l}\text { L pallidum, putamen, corona radiata } \\
\text { (circumscribed) - compression of } \\
\text { thalamus }\end{array}$ & $\sim 18$ \\
\hline 12 & $F / 19 / 9$ & 70 & $\begin{array}{l}\text { Chorea } \\
\mathrm{r} \text { arm }>\text { leg } \\
\text { marked on action }\end{array}$ & $\begin{array}{l}\text { Behavioural disorder, } \\
\text { r hemihypesthesia }\end{array}$ & $\mathbf{R}$ & II & $\begin{array}{l}\text { L subthalamus, internal capsule, medial } \\
\text { caudate, posterobasal pallidum } \\
\text { (circumscribed) }\end{array}$ & $\sim 18$ \\
\hline 13 & $\mathrm{~F} / 10 / 9$ & 60 & $\begin{array}{l}\text { Dystonia } \\
1 \text { arm }>\text { leg } \\
\text { Chorea-Ballismus } \\
1 \text { arm }>\text { leg }\end{array}$ & Precocious puberty & $\mathbf{L}$ & I & $\begin{array}{l}\mathbf{R} \text { subthalamus, thalamus, internal } \\
\text { capsule, corona radiata, crus cerebri } \\
\text { (circumscribed) }\end{array}$ & $\sim 25$ \\
\hline 14 & $F / 12 / 3$ & 60 & $\begin{array}{l}\text { Tremor, } 3-5 \mathrm{~Hz} \\
1 \text { arm: rest, post, int }\end{array}$ & Seizures, gait ataxia & $\mathbf{L}$ & II & $\begin{array}{l}\mathbf{R} \text { thalamus, quadrigeminal plate } \\
\text { (circumscribed) }\end{array}$ & $\sim 25$ \\
\hline 15 & $M / 16 / 15$ & 40 & $\begin{array}{l}\text { Dystonia + Chorea } \\
1 \text { arm > leg > face: rest, on } \\
\text { action }\end{array}$ & $\begin{array}{l}\text { Obtundation, 3rd nerve } \\
\text { palsy, cachexia }\end{array}$ & L & IV & $\mathrm{R}$ thalamus, upper brainstem $(\varnothing \mathrm{CT})$ & $>30$ \\
\hline 16 & $\mathrm{~F} / 62 / 59$ & 60 & $\begin{array}{l}\text { Tremor, high-frequency } \\
\text { bilateral, } 1>\mathrm{r} \\
\text { fingers }+ \text { eyelids }\end{array}$ & $\begin{array}{l}\text { Psychosis, lethargy, } \\
\text { dysarthria }\end{array}$ & $\mathbf{R}$ & II & $\begin{array}{l}\text { L anterior-ventrolateral thalamus } \\
\text { subthalamus, internal capsule, crus } \\
\text { cerebri (circumscribed) }\end{array}$ & $\sim 7$ \\
\hline 17 & $\mathrm{~F} / 13 / 11$ & 70 & $\begin{array}{l}\text { Dystonia, } r \text { arm: rest, } \\
\text { on action } \\
\text { Myoclonus, } r \text { shoulder }\end{array}$ & Dysarthria & $\mathbf{R}$ & I & $\begin{array}{l}\text { L hypothalamus, thalamus extending } \\
\text { over midline and to midbrain }(\varnothing \mathrm{CT})\end{array}$ & $\sim 25$ \\
\hline 18 & $F / 3 / 2$ & 70 & $\begin{array}{l}\text { Tremor, } 3-4 \mathrm{~Hz} \\
\mathrm{r} \text { arm: int }\end{array}$ & $\begin{array}{l}\text { Behavioural disorder, } \\
\text { anorexia, diminished } \\
\text { vision } 1 \text { eye }\end{array}$ & - & I & $\begin{array}{l}\text { L hypothalamus, thalamus } \\
\text { (circumscribed) }\end{array}$ & $\sim 20$ \\
\hline 19 & $\mathrm{~F} / 5 / 5$ & 60 & $\begin{array}{l}\text { Dystonia, } r \text { arm: rest, on } \\
\text { action }\end{array}$ & $\begin{array}{l}\text { Behavioural disorder, } \\
\text { diminished vision } 1 \text { eye }\end{array}$ & $\mathbf{R}$ & I & $\begin{array}{l}\text { L subthalamus, thalamus, caudate, } \\
\text { internal capsule, pallidum, putamen, } \\
\text { insula, uncus (circumscribed) }\end{array}$ & $\sim 20$ \\
\hline 20 & $\mathrm{~F} / 12 / 10$ & 60 & $\begin{array}{l}\text { Tremor, } 3-4 \mathrm{~Hz} \\
\mathrm{r} \text { arm: int }\end{array}$ & $\begin{array}{l}\text { Impaired memory, } \\
\text { behavioural disorder, } \\
\text { diminished vision } 1 \text { eye }\end{array}$ & $\mathbf{R}$ & I & $\begin{array}{l}\text { L thalamus, subthalamus, crus cerebri } \\
\text { (circumscribed) }\end{array}$ & $\sim 16$ \\
\hline
\end{tabular}

$\mathrm{M}=$ male, $\mathrm{F}=$ female, $\mathrm{KPS}=$ Karnofsky Performance Scale, $\mathrm{R}=$ right, $\mathrm{L}=$ left. Tremor is qualified as: rest-tremor at rest, post-postural tremor and int-intention tremor.

appeared to be more or less circumscribed. In patients 6 and 9 (fig 1) the neoplasm involved the basal ganglia and large parts of the hemisphere diffusely. The tumour volume ranged from 1.5 to more than $100 \mathrm{~cm}^{3}$. It was located in the contralateral basal ganglia in patients with unilateral MDs.

Twelve patients had tremor. Only patient 5 had Parkinsonism with bilateral rigidity, resting and postural tremor, akinesia, masked face, and loss of postural reflexes, though tremor was also present on action. In this case the tumour was located in the midline and involved both thalami, but exerted marked compression on the midbrain. Patient 16 had a high-frequency tremor of fingers and eyelids, presumably essential tremor, which was less severe on the right, slightly hemiparetic side contralateral to the tumour. The tumour predominantly involved the anterior and ventrolateral thalamus (fig 2). Ten patients had unilateral tremor, which in two was only present on action, in two others on action and on maintaining antigravity posture, and in six a combined resting-postural-intention tremor was found. These tremors had a frequency of 3 to $5 \mathrm{~Hz}$. The slight increase in tone in some patients with an ipsilateral hemiparesis had features of spasticity rather than of rigidity. Tremor in these patients was not associated with akinesia or impaired postural reflexes. In nine of these patients the tumour involved the 
Figure 1 Axial enhanced CT scans of patient 9 with right resting, postural and intention $4 \mathrm{~Hz}$ tremor WHO grade II astrocytoma of the left contralaterally via the corpus callosum. show a diffusely spreading basal ganglia and hemisphere extending

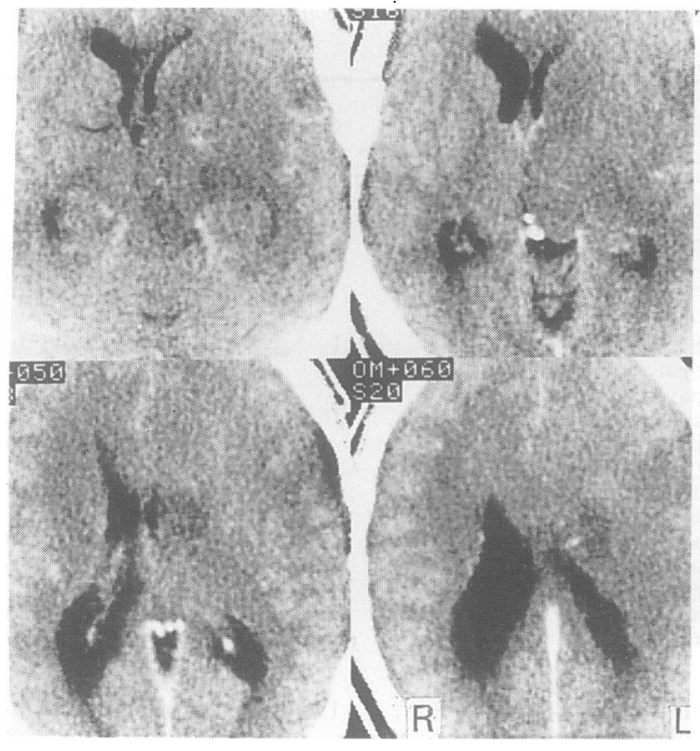

thalamus. In the tenth (case 11) the tumour was predominantly located in the pallidum and putamen, sparing the thalamus, but nevertheless exerted considerable compression on the thalamus. In patient 3 the tumour was located mainly in the red nucleus and to a lesser degree in the postero-basal thalamus (fig 3). In patient 14 the astrocytoma extended from the thalamus to the quadrigeminal plate (fig 4).

Hemidystonia or hemiathetosis was seen in eight patients, in five of whom it was particularly marked on action. The arm was affected in all these patients, with additional involvement of the leg in two. Patients 2 and 8 with involvement only of hand and fingers had an astrocytoma confined to the thalamus. In patients 10 and 19 the tumour mainly involved the caudate and putamen, to a lesser degree

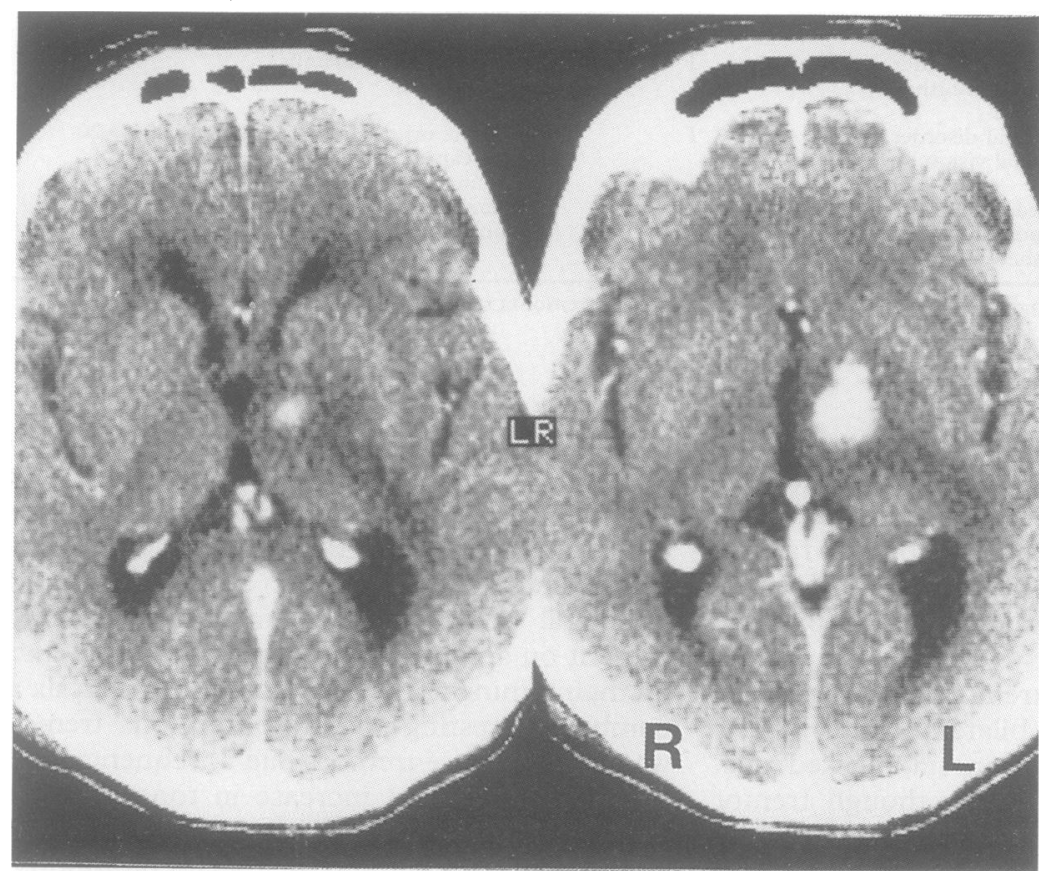

Figure 2 Enhanced CT scans of patient 16 with essential tremor showing a WHO grade II astrocytoma (focal anaplastic transformation could not be excluded) located predominantly in the left anterior/ventrolateral thalamus and the genu of the internal capsule.

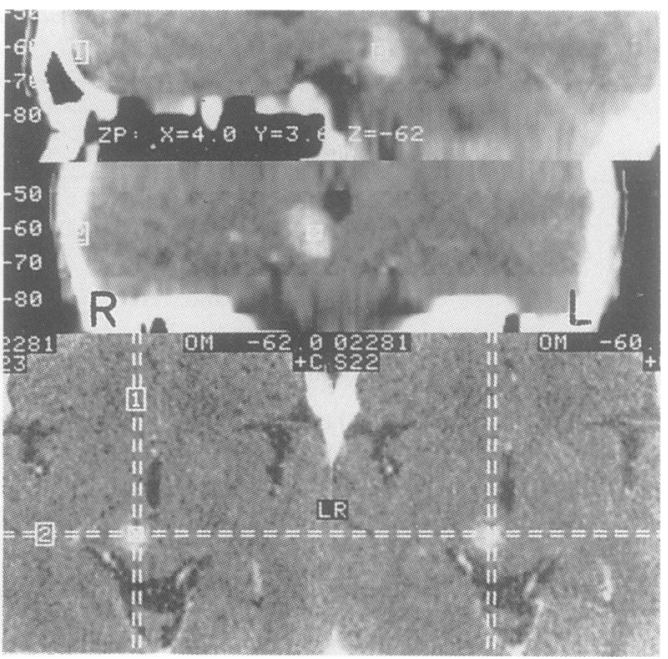

Figure 3 Axial enhanced CT scans (lower row) with sagittal (upper row) and coronal (middle row)

reconstructions of patient 3 with left resting, postural and intention 3-4 Hz tremor showing a relatively small

circumscribed WHO grade I astrocytoma, predominantly

located in the right red nucleus and posterobasal thalamus.

the thalamus. In cases 13,15 , and 17 the main tumour mass was found in the thalamus, whereas in case 7 the thalamus only was compressed.

Choreatic MDs were seen in four patients. Two had hemichorea, one left hemichorea involving the face markedly on the left side, and one hemichorea/hemiballismus. Patients 13 and 15 presented with hemichorea and dystonia appearing as "choreoathetosis". Hemichorea was associated in two patients with involvement of the head of the caudate. In the patient with hemichorea/hemiballismus, the thalamic tumour involved the subthalamic nucleus. Choreatic hyperkinesias disappeared in all patients in the long term.

The following data were analysed comparatively for patients with and without MDs. The female/male ratio was $1 \cdot 2: 1$ ( 11 females $/ 9$ males) for $M D$ patients and 1:1 for those without (102/103). The 20 astrocytomas of the MD patients and the 205 astrocytomas of those without were distributed according to histological grading as follows: WHO I -12 $(60 \%) / 41 \quad(20 \%)$; WHO II-6 (30\%)/71 (35\%); WHO III-0/56 (27\%); and WHO IV-2 $(10 \%) / 37(18 \%)$. In patient 16 the tumour was graded histologically as an astrocytoma WHO II, however, focal anaplastic transformation could not be excluded. The frequency of MDs in patients with low-grade $(\mathrm{I}+\mathrm{II})$ astrocytomas was $15 \%$, in patients with high-grade (III + IV) astrocytomas $2 \cdot 1 \%$. This difference was statistically significant $(p=0.0017)$. The mean age of patients with MDs at the time of biopsy was lower (24 years) than that of the patients without (36 years), however, the proportion of low-grade astrocytomas was higher in MD patients and the mean age correlated with histological grading as follows: WHO I (mean age in years, $\mathrm{MD}$ patients/patients without) 15/20; WHO II-36/35; WHO III- - 42 ; and WHO IV-43/47. There was also a trend for the mean age in patients with astrocytomas 


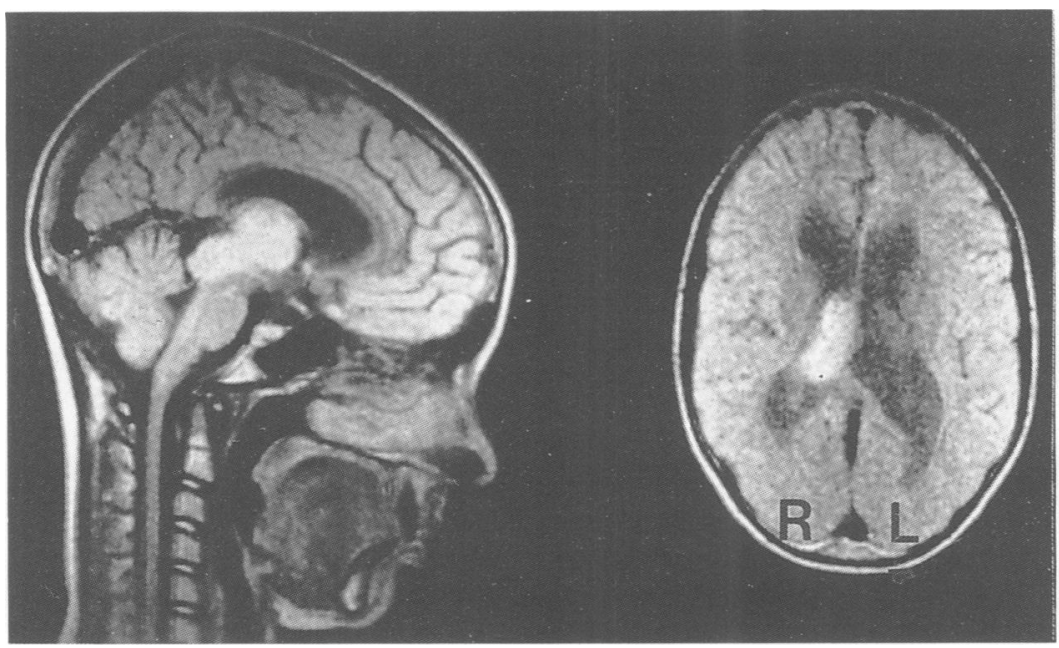

Figure 4 Sagittal SE 1040/40 and axial SE 1200/80 MR images of patient 14 with left resting, postural and intention 3-5 Hz tremor reveal a WHO grade II astrocytoma, predominantly located in the right thalamus and the quadrigeminal plate.

WHO I to be lower in MD patients ( 15 years) compared with those without (20 years).

Analysis of the CT data of patients with and without $\mathrm{MD}$ yielded no difference concerning the involvement of different anatomical structures. Comparing tumour volumes there was a different distribution, which reached statistical significance: $M D$ patients more often had tumour volumes ranging from 16 to $25 \mathrm{ccm}$ $(55 \%)$ than those without $(17 \%)$. However, large tumours were found more often in astrocytomas WHO III and IV.

Seventy per cent of patients with MDs and $73 \%$ of patients without had a hemiparesis of variable degree contralateral to the tumour. In the astrocytoma WHO I group there was a tendency for $\mathrm{MD}$ patients to present more often with hemiparesis $(75 \%)$ than those without $(61 \%)$. The median Karnofsky Performance Score $^{20}$ (KPS) in MD patients was 60. Considering the interrater variability the distribution of the KPS of patients with and without MD was similar.

\section{Discussion}

The frequency reported for MDs in patients with tumours of the basal ganglia and the thalamus varies considerably. It ranged from 1 to $33 \%^{1-7} 9_{1021-24}$ (table 2 ) in previous studies

Table 2 Large series of patients with tumours of the thalamus and the basal ganglia

\begin{tabular}{lcc}
\hline $\begin{array}{l}\text { Literature Review } \\
\text { (by first author) }\end{array}$ & \multicolumn{2}{c}{$\begin{array}{c}\text { Number of patients with movement } \\
\text { disorders/Total number of patients }\end{array}$} \\
\hline Ody, 1932 & $4 / 25$ & $16 \%$ \\
Globus, 1942 & $3 / 21 \star$ & $14 \%$ \\
Arseni, 1958 & $5 / 50 \star$ & $10 \%$ \\
Roth, 1958 & $7 / 34 \star$ & $21 \%$ \\
McKissock, 1958 & $8 / 24 \star \star$ & $33 \%$ \\
Tovi, 1961 & $2 / 49 \star / \star \star$ & $4 \%$ \\
Tolosa, 1965 & $15 / 61$ & $25 \%$ \\
Cheek, 1966 & $? / 51 \star / \star \star$ & $4 \mathrm{rare"}$ \\
Paillas, 1970 & $13 / 55 \star$ & $23 \%$ \\
Hirose, 1975 & $4 / 18 \star \star$ & $22 \%$ \\
Bernstein, 1984 & $4 / 60 \star / \star \star$ & $7 \%$ \\
Beks, 1987 & $? / 27 \star / \star \star$ & $?$ \\
Kelly, 1989 & $1 / 72$ & $1 \%$ \\
Krauss, 1992 & $20 / 225$ & $9 \%$ \\
\hline$\star$ : Series with different types of histological diagnoses, but \\
mainly astrocytomas I-IV.
\end{tabular}

and our study was $9 \%$. However, in some studies a histological diagnosis was not established in all patients and different histological diagnoses were grouped together without specifying separately those with astrocytomas, so that an exact comparison cannot be made. Only three series on tumours of the basal ganglia and the thalamus which mentioned patients with movement disorders dealt with histologically verified astrocytomas for the total study population or a defined subgroup. $^{71021}$ Since the involvement of the basal ganglia and thalamus in astrocytomas is different from that in other neoplasms, it may be better to consider the former tumours separately. The incidence of MDs seems to be generally lower in recent than in earlier studies. This might be explained by the availability of CT and MRI which also reveal smaller and oligosymptomatic tumours, and by the use of stereotactic techniques to establish an earlier histological diagnosis. We chose biopsy as the timepoint for calculating the incidence of MDs, since later MDs may be altered by, or even result from, therapeutic measures.

Previous series on basal ganglia and thalamic tumours differ considerably with respect to the proportion of low- or high-grade astrocytomas in MD patients. While some series report that the majority of patients had "malignant gliomas"23 or glioblastomas, ${ }^{10}$ others stress that most of the tumours producing "extrapyramidal" symptoms grow "very or rather" slowly. ${ }^{25}$ In our study MDs were found significantly more often in low-grade astrocytomas.

Although well documented cases of basal ganglia and thalamic tumours presenting with MDs and ipsilateral hemiparesis had been published earlier ${ }^{2126}$ sparing of the corticospinal tract was regarded as essential for MDs to occur. ${ }^{2325}$ In contrast, our data show that tremors as well as dystonia and chorea may be associated with a mild or moderate degree of hemiparesis. Comparing the patients with and without MDs we did not find a significant difference in the frequency of corticospinal tract dysfunction.

Unlike previous series and case reports on histologically verified astrocytomas of the basal ganglia and the thalamus the distribution of MDs differs in our study ${ }^{278101221-2325-41}$ (table 3 ). We observed comparatively more cases with dystonia and chorea. In patients with dystonia the thalamus was involved more frequently than the caudate or putamen. However, there may be secondary putaminal involvement due to the mass effect of the tumour. Clinicopathological correlations reported previously demonstrate primary lesions in caudate or putamen in the majority of cases with secondary dystonia. ${ }^{124243}$ Choreatic hyperkinesias, which were transient in our patients, seem to be rare in basal ganglia tumours. We found only one case in the literature and six of "choreoathetosis". Hemiballismus was described in a cystic midbrain glioma, ${ }^{14}$ but as far as we know, not in thalamic or basal ganglia astrocytomas.

Tremor was the most frequent MD in our 
Table 3 Movement disorders in patients with histologically verified astrocytomas of the thalamus and the basal ganglia: literature review and present series

\begin{tabular}{|c|c|c|c|}
\hline Movement Disorder & $\begin{array}{l}\text { Present Study } \\
\text { Number of Patients }\end{array}$ & $\begin{array}{l}\text { Literature Review } \\
\text { Number of Patients }\end{array}$ & $\begin{array}{l}\text { By first Author } \\
\text { (Number of Patients) }\end{array}$ \\
\hline Tremor/Parkinsonism & 12 & 47 & $\begin{array}{l}\text { Alexander (1), Arseni (5), } \\
\text { Bailey (1), Brzezicki (1), } \\
\text { Cheek (3), Coers (1), } \\
\text { Garcin (1), Globus (2), } \\
\text { Kelly (1), Kulali (1), } \\
\text { McGirr (1), Mettler (1), } \\
\text { Ody (3), Polyzoidis (1), } \\
\text { Roth (5), Sciarra (3), Smyth (1), } \\
\text { Tolosa (15) }\end{array}$ \\
\hline Myoclonus & 1 & - & - \\
\hline Chorea/Ballismus & 1 & - & - \\
\hline $\begin{array}{l}\text { Chorea } \\
\text { "Choreoathetosis" }\end{array}$ & $\begin{array}{l}3 \\
(2)\end{array}$ & $\begin{array}{l}1 \\
6\end{array}$ & $\begin{array}{l}\text { Alexander (1) } \\
\text { Arseni (2), Millichap (1), } \\
\text { Ody (1), Parker (1), } \\
\text { Roth (1) } 21 \text { 23636 33 }\end{array}$ \\
\hline Dystonia/Athetosis & 8 & 7 & $\begin{array}{l}\text { Chorobski (1), Marsden (2), } \\
\text { Masten (1), Narbona (1), } \\
\text { Sciarra (1), Urechia (1) } 3438.41\end{array}$ \\
\hline
\end{tabular}

series as well as in the literature. Interpretation of the literature is limited, since in the 47 cases of basal ganglia and thalamic astrocytomas we collected from 1927-91 (table 3) data concerning frequency and characteristics of the tremor were not always reported and the interpretations have differed considerably. While McKissock pointed out that the tremor was not "parkinsonian" in any of the eight cases he presented, ${ }^{3}$ it was stated to be "parkinsonian" in all patients with tremor in other series. ${ }^{610}$ As was pointed out by Ody, "rigor" or "rigidity" in some patients with space occupying cerebral tumours may have been more a sign of partial decerebration than a Parkinsonian feature. ${ }^{21}$ Although the tremor observed in some patients of this study had a frequency corresponding to Parkinsonian tremor, it differed in other characteristics. It was present on, or even only on, intended movements and was not accompanied by rigidity. Only one patient had tumour-induced Parkinsonism. Categorisation of these tremors raises certain difficulties. ${ }^{164445}$ Tremors have been denominated according to proven or assumed distinct lesions generating different types of tremor. In our opinion, however, denotation following clinical phenomena should not have topological or anatomical implications: "midbrain tremor", "rubral tremor" or "cerebellar tremor at rest". Thus we would not label the tremor in our patients as "thalamic", although there is evidence that tremor-driving impulses might originate in the thalamus. ${ }^{46}$ Furthermore, as stated above, axial CT scans may be inadequate to determine exactly the direct or indirect extension of involvement of the upper midbrain. Involvement of thalamic projections from cerebellar nuclei might be the common denominator for postural and intention tremors, with an additional structural or functional lesion of the red nucleus and/or the substantia nigra and their projections being necessary to produce rest tremor. Tumour-induced Parkinsonism seems to be more common in extra-axial than in intrinsic tumours. ${ }^{33}$

We could not find previous reports on the effect of thalamic or basal ganglia tumours on pre-existing movement disorders. In patient 16, who presumably had essential tremor, the rightsided tremor may have been less marked because of slight hemiparesis. However, it is also conceivable that it was reduced due to the tumour being located mainly in the left ventrolateral thalamus exerting a functional suppression.

We think that clinicopathological correlations in thalamic and basal ganglia astrocytomas should be made only with certain reservations. Interaction of different mechanisms may or may not lead to clinical symptoms. Functional lesions of the structures involved primarily by the tumour might result from "internal" compression of neurons or neural pathways or from altered metabolism by reduced vascular supply. But tumours or a peritumoural oedema may also induce symptoms by "external" compression of adjacent structures or their vascular supply. ${ }^{47}$ The question has been raised as to why tumours of the basal ganglia are not associated with MDs more often. The situation becomes more complex, since these tumours may also involve structures of the basal ganglia which are known to abolish or to reduce MDs when lesioned(predominantly the ventrolateral thalamus, the zona incerta, the pulvinar thalami and the internal pallidum and their fibre connections). Again these structures may be functionally damaged by "external" compression.

Neither necropsy findings nor the present comparative analysis of in vivo CT data showed topographical differences in thalamic and basal ganglia astrocytomas that do or do not cause MDs. However, tumours which are apparently identical on imaging studies may nevertheless differ in functional terms. These aspects might be at least partly explained using models such as that of parallel distributed processing ${ }^{48}$ provided more detailed information were available. However, the functional state of the basal ganglia in brain tumours causing MDs has only rarely been studied. In a case of a left frontal meningioma with right hemi-Parkinsonism PET indicated impaired oxygen metabolism and tissue perfusion in the striatopallidal region. ${ }^{49}$ In one case of Parkinsonism secondary to a craniopharyngioma biochemical findings on necropsy revealed considerably reduced striatal catecholamines and severely decreased dopamine receptor binding sites in the caudate. ${ }^{\text {so }}$ Further functional studies are needed and should provide deeper insights into the pathophysiological processes underlying the generation of movement disorders.

We thank G Pfister, H Förster and V Sonntag-O'Brien for technical assistance and preparation of the manuscript and $H$ Krauss for translation of the French literature.

1 Arseni C. Tumors of the basal ganglia. Arch Neurol Psychiat 1958;80:18-24.

Cheek WR, Taveras JM. Thalamic tumors. $f$ Neurosurg 1966;24:505-13.

3 McKissock W, Paine KWE. Primary tumours of the thalamus. Brain 1958;81:41-63.

4 Tovi D, Schisano G, Liljequist B. Primary tumors of the region of the thalamus. I Neurosurg 1961;18:730-40.

5 Bernstein M, Hoffiman HJ, Halliday WC, Hendrick EB, Humphreys RB. Thalamic tumors in children. 7 Neurosurg 1984;61:649-56.

6 Paillas JE, Legre J, Alliez B, Dufour M. Approche du diagnostic et du traitement des tumeurs des noyaux gris 
centraux. Neurochirurgie 1970;216:89-115.

7 Kelly PJ. Stereotactic biopsy and resection of thalamic astrocytomas. Neurosurgery 1989;25:185-95.

8 McGirr SJ, Kelly PJ, Scheithauer BW. Stereotactic resection of juvenile pilocytic astrocytomas of the thalamus and basal ganglia. Neurosurgery 1987;20:447-52.

9 Beks JWF, Bouma GJ, Journée HL. Tumours of the thalamic region. Acta Neurochir 1987;85:125-7.

10 Tolosa E, Vilato J, Fuenmayor P. Parkinsonisme tumoral. Neurochirurgie 1966;12:555-60.

11 Lakke JPWF, Barbeau A, Duvoisin RC, Gerstenbrand F Marsden CD, Stern G. Classification of extrapyramida disorders. F Neurol Sci 1981;51:311-27.

12 Marsden CD, Obeso JA, Zarranz JJ, Lang AE. The anatomical basis of symptomatic hemidystonia. Brain 1985;108:463-83.

13 Krauss JK, Mohadjer M, Wakhloo AK, Mundinger F. Dystonia and akinesia due to pallidoputaminal lesions after disulfiram intoxication. Mov Disord 1991;6: 166-70.

14 Dewey RB Jr, Jankovic J. Hemiballism-Hemichorea. Clinical and Pharmacological Findings in 21 Patients. Arch Neurol 1989;46:862-7.

15 Krauss JK, Mohadjer M, Nobbe F, Mundinger F. Bilateral ballismus in children. Child's Nerv Syst 1991;7:342-6.

16 Sabra AF, Hallett M. Action tremor with alternating activity in antagonist muscles. Neurology 1984;34:151-6.

17 Riechert T, Mundinger F. Beschreibung und Anwendung eines Zielgerätes für stereotaktische Hirnoperationen (2. Modell). Acta Neurochir 1956;3:308-37.

18 Mundinger F. CT-stereotactic biopsy for optimizing the therapy of intracranial processes. Acta Neurochir Suppl 1985;35:70-4.

19 Mundinger F, Braus DF, Krauss JK, Birg W. Long-term outcome of 89 low-grade brain-stem gliomas after interstitial radiation therapy. $\mathcal{F}$ Neurosurg 1991;75:740-6.

20 Karnofsky DA, Burchenal JH. The clinical evaluation of chemotherapeutic agents in cancer. In: MacLeod CM, ed. Evaluation of Chemotherapeutic Agents. New York: Columbia University Press, 1949:191-205.

21 Ody F. Tumors of the basal ganglia. Arch Neurol Psychiatr dy F. Tumors of

22 Globus JH, Kuhlenbeck $H$. Tumors of the striatothalamic and related regions. Arch Pathol 1942;34:674-734.

23 Roth RL, Bebin J. Cerebral hemispheric tumors and extrapyramidal signs and symptoms. Neurology 1958;8: 277-84.

24 Hirose G, Lombroso CT, Eisenberg H. Thalamic tumors in childhood. Arch Neurol 1975;32:740-4.

25 Arseni C, Nash F, Samitka DC. Extra-pyramidal syndromes with intracranial tumour. Psychiat Neurol 1959;137: 230-44.

26 Mettler FA, Davidoff LM, Grimes R. Static tremor with hemiplegia. Arch Neurol Psychiat 1947;57:423-9.

27 Alexander L. The fundamental types of histopathologic changes encountered in cases of athetosis and paralysis agitans. In: Basal ganglia, ARNMD: XXI. Baltimore: Williams and Wilkins, 1942:464-8. (cited by Roth et Bebin).

28 Bailey P, Buchanan DN, Bucy PC. Intracranial tumors of infancy and childhood. Chicago: University of Chicago Press, 1939.

29 Brzezicki E. Der Parkinsonismus symptomaticus. Schweiz Arch Neurol Psychiat 1929;25:56-88.
30 Coers C, Kleyntjens F, Brihaye J. Syndrome parkinsonien d'origine tumorale. Acta Neurol Belg 1952;52:737-65.

31 Garcin R, Klein MR, Kipfer M, Bozec L. Hémisyndrome parkinsonien gauche par tumeur fronto-calleuse droite disparaissant completement apres ablation de celle-ci. Rev Neurol 1943;3:80-3.

32 Kulali A, Tugtekin $M$, Ütkür Y, Erkurt S. Ipsilateral hemiparkinsonism secondary to an astrocytoma. $\mathcal{F}$ Neurol Nemiparkinsonism secondary to an

33 Polyzoidis KS, McQueen JD, Rajput AH, MacFadyen DJ. Parkinsonism as a manifestation of brain tumor. Surg Neurol 1985;23:59-63.

34 Sciarra D, Sprofkin BE. Symptoms and signs referable to the basal ganglia in brain tumor. Arch Neurol Psychiat 1953;69:450-61.

35 Smyth GE, Stern K. Tumours of the thalamus-a clinicopathological study. Brain 1938;61:339-74.

36 Millichap JG, Miller RH, Backus RE. Intracranial tumors in childhood. FAMA 1962;179:589-93.

37 Parker HL. Tumors of the brain simulating epidemic encephalitis and involving the third ventricle, the fourth ventricle, and the basal ganglia: report of three cases. 7 Nerv Ment Dis 1923;58:1-15.

38 Chorobski J. Involuntary movements in patients with intracranial tumors. Arch Neurol 1962;6:27-42.

39 Masten MG. Spongioblastoma of diencephalon. $f$ Nerv Ment Dis 1938;87:322-4.

40 Narbona J, Obeso JA, Tunon T, Martinez-Lage JM, Marsden CD. Hemi-dystonia secondary to localised basal ganglia tumour. F Neurol Neurosurg Psychiatry 1984; 47:704-9.

41 Urechia CI, Dragomir L, Usinievici G. Spasme de torsion unilatéral causé par une tumeur cérébrale. Confin Neurol 1942/43;5:271-80.

42 Pettigrew LC, Jankovic J. Hemidystonia: a report of 22 patients and a review of the literature. $f$ Neurol Neurosurg Psychiatry 1985;48:650-7.

43 Krauss JK, Mohadjer M Braus DF, Wakhloo AK, Nobbe F, Mundinger F. Dystonia following head trauma-a report of 9 patients and

44 Goldberger ME, Growden JH. Tremor at rest following cerebellar lesions in monkeys: effect of L-Dopa administration. Brain Research 1971;27:183-7.

45 Koppel BS, Daras M. "Rubral" tremor due to midbrain toxoplasma abscess. Mov Disord 1990;5:254-6.

46 Narabayashi H. Tremor mechanisms. In: Schaltenbrand G, Walker AE, eds. Stereotaxy of the human brain. Stuttgart, New York: Thieme, 1982:510-4.

47 Krauss JK, Mohadjer M, Nobbe F, Scheremet R. Hemidystonia due to a contralateral parieto-occipital metastasis: disappearance after removal of the mass lesion. Neurology 1991;41:1519-20.

48 Mitchell IJ, Brotchie JM, Brown GDA, Crossman AR. Modeling the functional organization of the basal ganglia. A parallel distributed approach. Mov Disord 1991; A parallel

49 Leenders KI, Findley LJ, Cleeves L. PET before and after surgery for tumor-induced parkinsonism. Neurology 1986;36:1074-8.

50 García de Yébenes J, Gervas J, Iglesias J, Mena MA, Del Rio RM, Somoza E. Biochemical findings in a case of parkinsonism secondary to brain tumor. Ann Neurol 1982;11:313-6. 